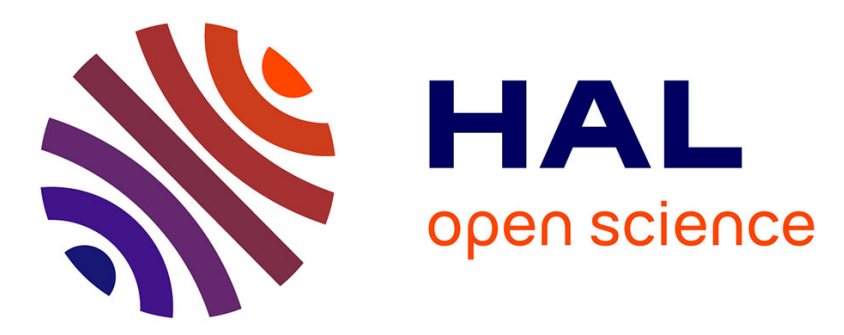

\title{
Acetylthiocholine (ATC) - cleaving cholinesterase (ChE) activity as a potential biomarker of pesticide exposure in the Manila clam, of Korea
}

Jin Young Choi, Jun Yu, Dong Beom Yang, Kongtae Ra, Kyung Tae Kim, Gi Hoon Hong, Kyung Hoon Shin

\section{To cite this version:}

Jin Young Choi, Jun Yu, Dong Beom Yang, Kongtae Ra, Kyung Tae Kim, et al.. Acetylthiocholine (ATC) - cleaving cholinesterase (ChE) activity as a potential biomarker of pesticide exposure in the Manila clam, , of Korea. Marine Environmental Research, 2011, 71 (3), pp.162. 10.1016/j.marenvres.2010.12.007 . hal-00673205

\section{HAL Id: hal-00673205 https://hal.science/hal-00673205}

Submitted on 23 Feb 2012

HAL is a multi-disciplinary open access archive for the deposit and dissemination of scientific research documents, whether they are published or not. The documents may come from teaching and research institutions in France or abroad, or from public or private research centers.
L'archive ouverte pluridisciplinaire HAL, est destinée au dépôt et à la diffusion de documents scientifiques de niveau recherche, publiés ou non, émanant des établissements d'enseignement et de recherche français ou étrangers, des laboratoires publics ou privés. 


\section{Accepted Manuscript}

Title: Acetylthiocholine (ATC) - cleaving cholinesterase (ChE) activity as a potential biomarker of pesticide exposure in the Manila clam, Ruditapes philippinarum, of Korea

Authors: Jin Young Choi, Jun Yu, Dong Beom Yang, Kongtae Ra, Kyung Tae Kim, Gi

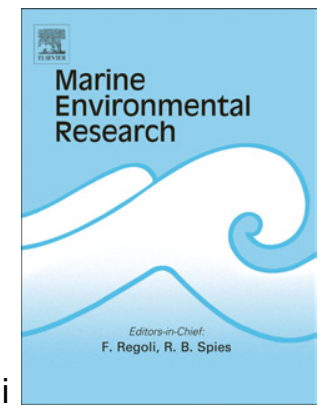
Hoon Hong, Kyung Hoon Shin

PII:

$$
\text { S0141-1136(10)00195-9 }
$$

DOI:

$$
\text { 10.1016/j.marenvres.2010.12.007 }
$$

Reference: MERE 3495

To appear in: Marine Environmental Research

Received Date: 16 July 2009

Revised Date: 22 December 2010

Accepted Date: 22 December 2010

Please cite this article as: Choi, J.Y., Yu, J., Yang, D.B., Ra, K., Kim, K.T., Hong, G.H., Shin, K.H. Acetylthiocholine (ATC) - cleaving cholinesterase (ChE) activity as a potential biomarker of pesticide exposure in the Manila clam, Ruditapes philippinarum, of Korea, Marine Environmental Research (2011), doi: 10.1016/j.marenvres.2010.12.007

This is a PDF file of an unedited manuscript that has been accepted for publication. As a service to our customers we are providing this early version of the manuscript. The manuscript will undergo copyediting, typesetting, and review of the resulting proof before it is published in its final form. Please note that during the production process errors may be discovered which could affect the content, and all legal disclaimers that apply to the journal pertain. 

20

\section{Acetylthiocholine (ATC) - cleaving cholinesterase (ChE)}

\section{activity as a potential biomarker of pesticide exposure in the}

\section{Manila clam, Ruditapes philippinarum, of Korea}

(1)

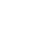

6

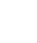

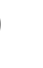

${ }^{a}$, Kyung Hoon Shin ${ }^{c}$

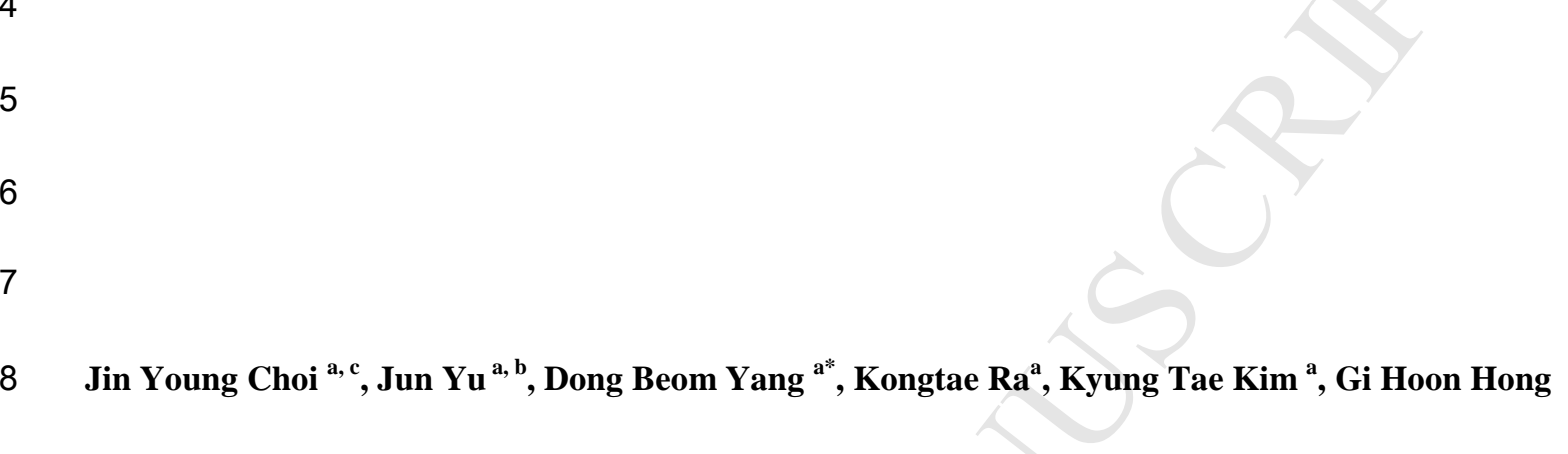

11

2

3

\footnotetext{
${ }^{a}$ Marine Environment and Pollution Prevention Research Department, Korea Ocean Research and Development
}

$$
\text { Institute (KORDI), Ansan, 426-744, Korea }
$$

$9 \quad{ }^{\mathrm{b}}$ Environment Research Department, National Fisheries Research and Development Institute, Busan, 619-902, Korea 


\section{ABSTRACT}

2

3 The acetylthiocholine (ATC) - cleaving cholinesterase (ChE) activity in Manila clam, which is

4 widely distributed throughout the coastal environment of Korea, was assayed as a potentially

5 useful biomarker of organophosphorous pesticides (OPs). A clear dose-response relationship

6 was determined between inhibited $\mathrm{ChE}$ in adductor muscle of clams and four OPs (methidathion,

7 chlorpyrifos, diazinon, IBP) which are heavily used OPs in Korea. The measured $\mathrm{EC}_{50}-24 \mathrm{~h}$

8 values of methidathion, chlorpyrifos, diazinon, and IBP for $R$. philippinarum were $7.16 \mu \mathrm{g}^{-1}$,

$90.34 \mathrm{mg} \mathrm{l}^{-1}, 3.01 \mathrm{mg} \mathrm{l}^{-1}$, and $3.41 \mathrm{mg} \mathrm{l}^{-1}$, respectively. In field studies, ChE activity in Manila

10 clams collected from 23 stations in the mid-western coastal region demonstrated spatial

11 variation with statistical differences. These results suggest that ChE activity in $R$. philippinarum

12 is a potential biomarker for assessing organophosphorous pesticide contamination in coastal

13 environments.

15 Keywords: Cholinesterase, biomarker, chlorpyrifos, IBP, organophosphorous pesticides (OPs),

16 Manila clam, Ruditapes philippinarum 


\section{Introduction}

The agricultural pollutants, including organophosphorous pesticides (OPs) and untreated municipal sewage, flow into intertidal and coastal zones, leading to significantly adverse environmental effects on aquatic organisms living there. Using biomarkers for coastal and marine pollution has many advantages when compared to chemical analysis. Among the biological effects of pollutants, biochemical changes occur more quickly than physiological responses and provide information on the sensitivity of organisms with regard to uptake, biotransformation, and detoxification patterns (Galloway et al., 2002). Biomarkers allow an integrated measurement of bioavailable contaminants causing biochemical responses, providing early indicators of potential pollution.

OPs, which are widely used agricultural pesticides, enter the marine environment by land runoff, leaching, erosion, or aerial deposition. Approximately 23 thousand tons of pesticide was used throughout Korea in 2007. Of this amount, OPs accounted for nearly 60\%. The toxic effects of OPs are caused by the irreversible inhibition of enzyme acetylcholinesterase (AChE), which hydrolyses the neurotransmitter acetylcholine (ACh) in the cholinergic synapse of the central and peripheral nervous system (Sturm et al., 2007). In many previous studies, AChE has been reported as a responsive biomarker to neurotoxic compounds, which include OPs, in biomonitoring studies that assess negative effects on aquatic organisms and environmental quality (Escartín and Porte, 1997; Radenac et al., 1998; Mora et al., 1999; Galgani and Bocquené, 2000; Dailianis et al., 2003).

Bivalves living in sandy-mud bottoms are often used for ecotoxicological monitoring because they are filter-feeding organisms and can accumulate contaminants in their tissues to relatively high levels. For instance, bivalve enzyme activity, including AChE, has already been 
extensively used in monitoring environmental pollution in laboratory and field studies (Le Bris et al., 1995; Dellali et al., 2001; Doran et al., 2001; Alves et al., 2002; Mohamed et al., 2003).

In a laboratory study, exposure to neurotoxic compounds resulted in decreased AChE activity of blue mussels (Escartín and Porte, 1997; Astley et al., 1999; McHenery et al., 1997; Mora et al., 1999; Alves et al., 2002). Variations in the AChE activity of marine mussels have frequently been observed in field studies with links to pollution levels, suggesting the presence of AChEinhibiting substances (Dailianis et al., 2003; Lionetto et al., 2003). Dellali et al. (2001) reported that the AChE activity of clams (Ruditapes decussatus) is generally lower than mussels (Mytilus gallovincialis) but showed greater spatio-temporal variability when compared to mussels.

The Manila clam, Ruditapes philippinarum, is a commercially important bivalve, as it is a fishery food resource in Korea. Approximately 38 thousand tons were harvested in 2007. Unlike mussels and oysters that inhabit only specific regions, the Manila clam $R$. philippinarum is widely distributed throughout intertidal regions along the western coast of Korea, demonstrating a high tolerance to a wide range of temperature and salinity (Laing and Child, 1996; Baudrimont et al., 2005). Sampling of this species is much easier than other bivalves in the coastal areas of Korea. Manila clams live in sandy-mud bottom and extrude their siphons to filter feed in the near bottom water (Toba et al., 1993), re-suspended benthic particles being the major food source. Manila clams are considered a suitable indicator of environmental contamination in various phases because they are exposed to both seawater and sediment.

AChE activity of invertebrates, in particular bivalves, differs from vertebrates. The classifications, characteristics and tissue localization of cholinesterase (ChEs) in vertebrates are generally are valid for invertebrates, but there are differences (Kristoff et al., 2006). ChE in invertebrates are able to cleave suitable substrates among acetylthiocholine (ATC), butylthiocholine (BTC) or propionylthiocholine (PrTC). ChE may exhibit a wide variety of 
1 substrate specificities (Kristoff et al., 2006). In some studies, ChE activity of invertebrates like

2 bivalves was measured with acetylthiocholine (ATC) as substrate (Bocquené et al., 1997;

3 Galgani, 1992).

4 In this study, the ATC-cleaving ChE activities of the Manila clam $R$. philippinarum were

5 studied to evaluate their sensitivity to exposure to common OPs (IBP, chlorpyrifos, diazinon,

6 and methidathion). In the following, the ATC-cleaving $\mathrm{ChE}$ activities were transcribed into $\mathrm{ChE}$

7 activity for convenience sake.

$8 \quad$ R. philippinarum were collected at 23 stations throughout the mid-western coast of Korea to

9 study the spatial variations of $\mathrm{ChE}$ in bivalves and determine the status of pollution in the study

10 areas. We discuss the possibility of ChE analysis in this species as a useful biomarker for OPs exposure in coastal regions influenced by nearby agricultural areas.

\section{Materials and Methods}

\subsection{Chemicals}

Molecular biology grades, including 5, 5'-dithio-bis-(2-ntrobezoic acid) (DTNB), Trizma $\mathrm{HCl}$,

Trizma base, acetylthiocholine, brilliant blue G, and bovine were purchased from Calbiochem and Sigma-Aldrich.

\subsection{Exposure experiments}

Laboratory exposure tests were performed to determine the dose-response relationship between ATC-cleaving ChE activity in Manila clam and the OPs. All specimens were collected from Oido (St.1) located on the western coast of Korea and acclimatized for $48 \mathrm{~h}$ (Fig. 1). 
1 similar size (average length: $3.45 \pm 0.18 \mathrm{~cm}$ ) in each tank. Time-dependent inhibition of ATC-

2 cleaving ChE activity in the Manila clams was assayed for $48 \mathrm{~h}$. Sampling was done at 0

3 (control), 8, 16, 24, 36, and $48 \mathrm{~h}$ intervals following exposure to $0.3 \mathrm{mg} \mathrm{l}^{-1}$ of chlorpyrifos.

4 Differing concentrations of technical grade chlorpyrifos, methidathion, IBP, and diazinon mixed

5 with pre-filtered seawater were added to the laboratory sample (temperature: $17-19^{\circ} \mathrm{C}$, salinity:

$630 \pm 0.5 \%$ o). Manila clams were incubated for $24 \mathrm{~h}$ in each acrylic vessel before the assay. All

7 ATC-cleaving ChE activity in clams exposed to four types of pesticides was measured

8 immediately following sampling.

9

2.3. Study area and sample collection

The tidal mud plat, the habitat of the Manila clam, is expansive on the western coast of Korea with an area of nearly $1980 \mathrm{~km}^{2}$, an area that makes up $83 \%$ of total tidal flat area on the Korean peninsula. Along the Midwestern coast of Korea, a number of large-scale farmlands heavily utilize pesticides, with river discharge from those areas resulting in large amounts of pesticides (including OPs) flowing into intertidal and coastal waters. To study the spatial variations of ATC-cleaving ChE activity in the Manila clam (R. philippinarum), specimens were collected from the sediment at 23 stations throughout the Midwestern coast of Korea from June - August 2001 (Fig. 1).

The average weight and length of specimens $(n=115)$ was $8.48 \pm 1.04 \mathrm{~g}$ and $3.38 \pm 0.14 \mathrm{~cm}$, respectively. All specimens were transferred to the lab and the adductor muscles of 5 clams 
1 from each station were immediately excised and stored at $-80^{\circ} \mathrm{C}$ to minimize enzyme

2 degradation before the enzyme assay.

3

$4 \quad 2.4$. ChE activity analysis

5

6

ATC-cleaving ChE activity was measured in the adductor muscle of individual clams. Approximately $0.1 \mathrm{~g}$ of adductor muscle was placed in $10 \mathrm{~mL}$ of buffer $(0.1 \mathrm{M}$ Tris buffer, Trizma $\mathrm{HCl}+$ Trizma base, $\mathrm{pH}$ 8.0) and homogenized for 1 min using Ultra-Turrax (IKA) at $4^{\circ} \mathrm{C}$. The homogenate was centrifuged at $10,000 \mathrm{~g}$ for $15 \mathrm{~min}$ at $4^{\circ} \mathrm{C}$. Measurements of ChE using a microplate reader were taken according to the methods detailed in Galgani (1992). $300 \mu \mathrm{l}$ of $0.1 \mathrm{M}$ Tris buffer, $20 \mu \mathrm{l}$ of $0.01 \mathrm{M}$ dithionitrobenzoic acid (DTNB), and $10 \mu \mathrm{l}$ of enzyme suspension were added to the 96 -well microplates. After 5 min of incubation at room temperature, the enzyme reaction was initiated with the addition of $0.1 \mathrm{M} 10 \mu \mathrm{l}$ acetylthiocholine (ATC) as the substrate according to Galgani (1992). The absorbance change was monitored at $405 \mathrm{~nm}$. Four replicates measurement were carried out for each sample. Protein analyses were carried out on the same homogenate using the techniques described by Bradford (1976). Enzyme activity was normalized to the protein content and specific activity was expressed as nmole $\min ^{-1} \mathrm{mg}^{-1}$ protein. In the following text, the ATC-cleaving ChE activities were transcribed into $\mathrm{ChE}$ activity for convenience sake.

\subsection{Statistical analysis}

Data from the laboratory and field studies were compared by one-way ANOVA. The results of the laboratory and field studies were statistically tested for homogeneity of variance and for normal distribution before one way ANOVA. Statistical differences between target groups were identified with Scheffe's post hoc test and Tukey's post hoc test. A half maximal effective 
1 concentration $\left(\mathrm{EC}_{50}\right)$ with a $95 \%$ confidence limit was determined by probit analysis.

2 Spearman's rank test was used to determine correlations between biomarker data and

3 environmental survey data. All statistical analyses were performed using the SPSS package for 4 windows (Version 11.5.0, SPSS, Chicago, IL).

5

6 3. Results

7

$8 \quad 3.1$. Laboratory exposure

9

- Position of Figure 2

Exposure experiments were carried out in the presence of different OPs (chlorpyrifos, diazinon, IBP, methidathion) at different concentrations according to their toxicity. In particular,

14 ChE activity in the adductor muscle of $R$. philippinarum exposed to $0.3 \mathrm{mg}^{-1}$ chlorpyrifos for $48 \mathrm{~h}$ was assayed to show time-dependent toxicity of chlorpyrifos. Reduced ChE activity of $R$. philippinarum was a function of exposure time at $0.3 \mathrm{mg} \mathrm{l}^{-1}$ (Fig. 2). After $24 \mathrm{~h}$ of exposure, ChE activity was reduced to $52.4 \%$, the difference being significant (Scheffe's post hoc test, $\mathrm{p}<$ 0.05 ) from the control. Only $25.8 \%$ of the original activity was determined after $48 \mathrm{~h}$ of exposure. This indicates the significant time-dependent variability of $\mathrm{ChE}$ in the adductor muscle of the Manila clam following exposure to chlorpyrifos, particularly $24 \mathrm{~h}$ after exposure.

- Position of Figure 3

The inhibition of ChE activity varied with different OP compounds and dose exposures. The 
1 average ChE activity was reduced for each OP compound (Fig. 3). Toxicity-dependent

2 variations of $\mathrm{ChE}$ activity and dose-response relationships according to OP type were observed.

3 ChE activity was reduced to $66.4 \%-34.4 \%$ with a dose range of 0.1 to $1.0 \mathrm{mg}^{-1}$ of

4 chlorpyrifos (Fig. 3a). Significant inhibition of $\mathrm{ChE}$ activity occurred with $0.1 \mathrm{mg} \mathrm{l}^{-1}$ of

5 chlorpyrifos (Scheffe's post hoc test, $p<0.05$ ). ChE activity decreased to $20.8 \%$ after exposure

6 to $0.1 \mathrm{mg} \mathrm{l}^{-1}$ diazinon (Fig. 3b), the difference being significant (Scheffe's post hoc test, $p<$

$7 \quad 0.05)$ from control. ChE activity $\left(2.0 \mathrm{mg}^{-1}\right)$ was reduced by nearly half when compared to the

8 control. Fig. 3c demonstrates ChE activity following exposure to IBP, which results in

9 concentration-dependent enzyme inhibition. ChE activity was reduced to $75.6 \%, 70.8 \%, 57.3 \%$, and $39.3 \%$, respectively, for different concentrations of IBP $\left(0.5,1.0,3.0\right.$, and $\left.5.0 \mathrm{mg} \mathrm{l}^{-1}\right)$. Reduced ChE activity as a result of different OPs followed the order chlorpyrifos > IBP > diazinon at $1.0 \mathrm{mg} \mathrm{l}^{-1}$ of concentration. Due to the acute toxicity of methidathion, a dose exposure range of $5-20 \mu \mathrm{g} \mathrm{l}^{-1}$ was used and demonstrated $\mathrm{ChE}$ activity reductions of $79.0-$ 26.4\%. Significant enzyme inhibition could be detected in manila clams at a lower concentration of methidathion than concentration of other OPs (Scheffe's post hoc test, $p<$ $0.05)$.

- Position of Table 1

The 24-h median effective concentration $\left(\mathrm{EC}_{50}-24 \mathrm{~h}\right)$ was calculated using probit analysis with a $95 \%$ confidence limit. The $\mathrm{EC}_{50}-24 \mathrm{~h}$ values for the Manila clam, $R$. philippinarum, were 7.16 $\mu \mathrm{g} \mathrm{l^{-1 }}$ for methidathion, $0.34 \mathrm{mg}^{-1}$ for chlorpyrifos, $3.01 \mathrm{mg} \mathrm{l}^{-1}$ for diazinon, and $3.41 \mathrm{mg}^{-1}$ for IBP. Toxic potency occurred in the order of methidathion $>$ chlorpyrifos $>$ diazinon $>$ IBP. The classification of pesticides by hazard (WHO, 2005) is included in Table 1 . This obtained results 
1 demonstrated the dose-dependent fashion of $\mathrm{ChE}$ activity in adductor muscle of $R$.

2 philippimarum caused by investigated OPs.

3

4 Position of Table 2

5

$6 \quad 3.2$. Field study

7 We present the results for ChE activity in the adductor muscle of $R$. philippinarum from 23

8 stations of the Western coast of Korea (Table 2). The mean ChE activity ranged from 6.14 to

$9 \quad 13.24$ nmole $\min ^{-1} \mathrm{mg}^{-1}$ protein. Spatial variations of clam ChE activity were shown along the sampling stations. The greatest ChE activity was measured at St. $10\left(13.24 \pm 6.13\right.$ nmole $\mathrm{min}^{-1}$ $\mathrm{mg}^{-1}$ protein), far from the major pollutant sources. ChE activity was statistically lower at St. 12, St. 16 (Tukey's post hoc test, $p<0.05$ ), and St. 14 (Tukey's post hoc test, $p<0.1$ ) than at the reference site (St. 10).

\section{Discussion}

4.1. ChE inhibition by organophosphorous pesticides

Although biomarkers are thought to play an important role in assessing the adverse effects of contaminants in marine and coastal organisms, the use of sentinel organisms, as well as the appropriate organs to use, remains up for debate. Metabolic mechanisms and uptake are unique to each organism. Plenty of contaminants affecting enzyme activity exist in marine environments. The Manila clams are widely distributed along the coasts of Korea, China, Japan, Northwestern America, and several European countries (Flassch and Leborgne, 1992). The adductor muscle of the Manila clam was selected for enzyme assay to investigate sensitivity of

24 ChE activity in adductor muscle of the clam to OPs exposure. Because of the adductor muscle's 
1 systematic function and easier separation from the body, the adductor muscle of bivalves and

2 mussels presents a popular option for measuring AChE activity in many studies (Le Bris et al.,

3 1995; Moulton et al., 1996; Doran et al., 2001; Romani et al., 2006). In this study, toxicity-dependent ChE inhibition was observed for four different pesticides. Increased inhibition of $R$. philippinarum $\mathrm{ChE}$ activity during pesticide exposure occurred with increased exposure time and increased pesticide concentration. ChE activity for methidathion samples was significantly lower than in samples exposed to other pesticides. The reported $\mathrm{LC}_{50}$ value of methidathion is 2-9 $\mathrm{mg}^{-1}$ in bluegill sunfish (Kidd et al., 1991; Mayer and Ellersieck, 1986).

Chlorpyrifos is a broad spectrum organophosphate insecticide and highly toxic compound. According to Doran et al., (2001), significant reductions in AChE activity for the adductor muscle of mussel, Amblema plicata, were demonstrated at a chlorpyrifos concentration range of 0.1-2.0 $\mathrm{mg} \mathrm{l}^{-1}$. In the adductor muscle of the Manila clam, R. philippinarum, our data also demonstrated significant reductions in ChE activity (35-67\%) relative to the control.

Diazinon and IBP are used worldwide to eliminate crop and cattle plagues, to control household pests (ATSDR, 1997), and as an agricultural fungicide in Asia. Cong et al. (2009) report that the brain ChE activity of the Snakehead fish (Channa striata) is significantly inhibited by diazinon. The $\mathrm{LC}_{50}$ of diazinon in rainbow trout is reported to be $2.6-3.2 \mathrm{mg}^{-1}$ (Kidd et al., 1991). The diazinon concentrations in seawater were below $0.02 \mathrm{mg} \mathrm{l}^{-1}$, which is a limited set in terms of the seawater quality standards of Korea (Choi et al., 2006). IBP, on the other hand, has been considered a contaminant with moderate levels $\left(40-3300 \mathrm{ng}^{-1}\right)$ in inshore waters, particularly in late summer (Yu et al., 2001; Choi et al., 2006). 
In this study, we evaluate the ChE activity of Clam, R. philippinarum, as potential biomarker of organophosphorous pesticide contaminant in coastal environments of Korea. The specimens collected from outer stations (St. 8, 9, and 10) receiving limited amount of agricultural runoff demonstrated relatively high $\mathrm{ChE}$ activity. Relatively high $\mathrm{ChE}$ activities were also found at stations 1, 5, 6 and 19 located near the harbor area. On the contrary, significantly low ChE activities were measured in clams from St. 12 through 16, which were located at Anmyon Island, an area with extensive agricultural activity. This indicates that $\mathrm{ChE}$ inhibition at these stations may be affected by the use of agricultural pesticides in tributaries. Extremely high variation in the AChE activity at stations characterized by intensive agricultural activity has been reported (Dellali et al., 2001; Matozzo et al., 2005). Other organisms (mussel and fish) also demonstrate large variations in AChE activity (Galloway et al., 2002; Oliviera et al., 2007).

The ChE activity of sample organisms can vary with biotic (class or species of bivalve or mussel, age, size, reproductive period, and physiological conditions) and abiotic factors related to the habitat (temperature, $\mathrm{pH}$, salinity, etc.). Previous studies indicated that variation in $\mathrm{AChE}$ activity of mussels was related to several other factors, including differences in sex, age, and size (Varela and Augspurger, 1996; Fairbrother et al., 1989). Pfifer et al. (2005) demonstrated a negative correlation between AChE activity of Mytilus sp. and salinity.

- Position of Table 3

During the extensive survey in the study area hydrologic parameters as well as concentrations of contaminants (OPs, PAHs, PCBs and $\mathrm{Cu}$ ) were measured at the same locations where manila clams were collected for enzyme assay. These data were reported elsewhere (KORDI, 2002). Salinity and the concentration of IBP (OPs) are summarized in Table 3. In the present study, no 
1 relationship between salinity and ChE activity was observed, as the salinity of surface water

2 ranged from $29.1-32.6 \%$ (Table 3b). The influence of size or physiological condition on the

3 ChE activity of the Manila clam is still largely unknown. We believe the effect of specimen size

4 on ChE activity to be negligible because similarly sized clams $(3.38 \pm 0.14 \mathrm{~cm}$ of average

5 length, $\mathrm{n}=115$ ) were used in this study. A greater body of data is necessary to elucidate the

6 intricate metabolic mechanisms that influence the inhibition of $\mathrm{ChE}$ activity.

7 Variations in the $\mathrm{ChE}$ activity of aquatic organisms may reflect various contaminants

8 including heavy metals, PAHs, hydrocarbons, detergents, phytotoxin, and other industrial

9 pollutants (Payne et al., 1996; Flammarion et al., 1996; Magni et al., 2006; Senger et al., 2006;

10 Linde-Arias et al., 2008; Bervoets et al., 2009). Combinations of OPs and other contaminants

11 are highly synergistic in their ability to inhibit AChE activity (Bocquené et al., 1995; Forget et 12 al., 1999).

13 First we compared ChE activity with concentrations of OPs, typical inhibitors of ChE activity, in seawater of the study area. OPs concentrations in seawater collected from the same stations were determined during the sampling period (KORDI, 2002). IBP was the most commonly detected OPs in the study area with concentrations ranging from from n.d. to $394 \mathrm{ng}$

$17 \mathrm{l}^{-1}$ (Table 3(a)). The concentrations of IBP reported by KORDI (2002) and ChE activities in clams of this study were statistically analyzed (Table 3(b)). The ChE activity in clams demonstrated a negative correlation with IBP concentrations in surface seawater $(p<0.05, \mathrm{r}=-$ 0.60 by nonparametric correlations, Spearman's rank test). Because IBP is widely and heavily used OPs in Korea, IBP may be inhibiting ChE in Manila clams. In a previous study, IBP concentrations recorded from inshore Korean waters during August ranged from about 40 $1840 \mathrm{ng} \mathrm{l}^{-1}$ (Yu et al., 2001). Other OPs (DDVP, disulfoton and chlorpyrifos) were not 
1 frequently detected in seawater during the study period. However we cannot exclude the

2 possible influence of other OPs since the spatial variations of ChE activity in the Manila clam

3 are expected to result not only from specific pesticide compounds, particularly IBP, but also

4 from multiple OPs in a synergetic effect.

5 In this study ChE activities of Manila clams were compared with concentration of IBP in the

6 seawater only. Manila clam lives in sandy-mud bottom with their body buried and siphons

7 extruding into the bottom water (Toba et al., 1993). The comparison of ChE activity with the concentration of OPs in sediments would be useful to understand the spatial variability of the enzyme. Unfortunately, the concentrations of IBP in the sediment were below detection limit during survey of KORDI (2002). It was difficult to measure OPs in sediments since the particle adsorption capacity of OPs are relatively low $\left(\log K_{o c}=3.5\right.$ for IBP $)$ and the half-lives of OPs are generally shorter than a few months. Furthermore sandy-mud sediments which prevail in the study area have low adsorption capability of organic materials.

It is highly possible that some amount of pesticides adsorbed on sediment particles would also influence the enzyme activity. It can also be assumed that area with high IBP concentration in seawater would have relatively high sediment IBP concentration. In this study ChE activities of Manila clams were compared with concentration of IBP in the seawater only.

It was found that some other contaminants such as PCB, PAH and their mixture showed ChE inhibition (Kang and Fang., 1997; Jett et al., 1999) or potential influence to ChE activity (Bonassi et al., 2009). To better understand the impact of other pollutants on the inhibition of ChE in this study, ChE activity in the adductor muscle of $R$. philippinarum was compared with polychlorobiphenyl (PCBs), poly-aromatic hydrocarbons (PAHs) and copper (Cu) concentrations in the sediments collected from the same stations. Total PCBs concentrations in the sediment were generally below $20 \mathrm{ng} \mathrm{g}^{-1} \mathrm{dw}$ in the study area. No statistically significant 
relationship existed between ChE activity and tPCBs concentrations measured in the sediment samples (Spearman's rank test, $p=0.311$ ). Total PAHs and $\mathrm{Cu}$ concentrations in sediment were in the range n.d. $-909.0 \mathrm{ng} \mathrm{g}^{-1} \mathrm{dw}$ and $\mathrm{n} . \mathrm{d}-16.0 \mu \mathrm{g} \mathrm{g} \mathrm{g}^{-1} \mathrm{dw}$, respectively. ChE activity in Manila clam did not show any significant relationship with PAHs (Spearman's rank test, $p=0.201$ ) and $\mathrm{Cu}$ (Spearman's rank test, $p=0.708$ ) concentration in sediment. The concentrations of PCBs, PAHs and $\mathrm{Cu}$ found in sediment of the study area were comparatively lower than the level, at which ChE inhibition might occur, reported by previous authors.

Monitoring ChE activity in aquatic species can certainly play an important role as an early warning of pesticide exposure. The coastal environment, including intertidal zones, is significantly affected by high levels of contaminants resulting from natural and anthropogenic inputs. The Manila clam, R. philippinarum, is widely distributed throughout the intertidal zone. Due to the limited mobility of clams compared to fish, clams are directly affected by continuous exposure to contaminants from potentially polluted sediment and seawater. It is necessary to determine the effects of OP compounds and other contaminants on ChE inhibition, in order to understand the seasonal variation of ChE activity. Our results suggest that the ChE activity of the Manila clam, R. philippinarum, is a good biomarker for organophosphorous pollution.

\section{Conclusion}

We determined the ATC-cleaving ChE activity of the Manila clam (R. philippinarum), widely distributed throughout intertidal zone of Korea, to be a suitable biomarker for addressing pesticide contamination. ChE activity in the adductor muscle of clams was significantly reduced with increases in organophosphorous pesticide (OPs) dose, indicating a clear dose-response relationship. Clams from the 23 stations on the mid-western coast of Korea indicated spatial 
1 variations in $\mathrm{ChE}$ activity. In order to explain the spatial variations in $\mathrm{ChE}$ activity various

2 contaminants in seawater and sediments of study area were compared to ChE activity. Only IBP

3 concentration in seawater showed a significant relationship with ChE activity in Manila clams.

4 Since Manila clams, $R$. philippinarum, dwell in the intertidal zone, they may experience the

5 greatest continuous exposure to OP contaminants. Our results suggest that ChE activity in the

6 adductor muscle of $R$. philippinarum can be effectively utilized as a biomarker of

7 organophosphorous pesticides (OPs) in the coastal and estuarine environment. More studies are

8 needed to better understand the influence of biotic and abiotic factors as well as other

9 contaminants (e.g., heavy metals, PAHs, PCBs, etc.) on ChE activity in R. philippinarum.

10

11 Acknowledgements

12 This work was supported by the Korea Ocean Research and Development Institute through the

13 "Land-Ocean Interaction in the Coastal Zone of Asan" project (PE98103). 


\section{References}

2

3 Alves, S.R.C., Severino, P.C., Ibbotson, D.P., Da Silva, A.Z., Lopes, F.R.A.S., Sáenz, L.A.,

4 Bainy, A.C.D., 2002. Effects of furadan in the brown mussel Perna perna and in the mangrove 5 oyster Crassostrea rhizophorae. Marine Environmental Research 54, 241-245.

6

7 Astley, K.N., Meigh, H.C., Glegg, G.A., Braven, J., Depledge, M.H., 1999. Multi-variate 8 analysis of biomarker responses in Mytilus edulis and Carcinus maenas from the Tees Estuary 9 (UK). Marine Pollution Bulletin 39, 145-154.

ATSDR, 1997. Agency for Toxic Substances and Disease Registry (ATSDR), 1997. Available in: (http://www.atsdr.cdc.gov/es/es_index.html)

Baudrimont, M.J., Schäfer, V., Marie, R., Maury-Brachet, C., Bossy, A.B., Blanc, G., 2005.

Geochemical survey and metal bioaccumulation of three bivalve species (Crassostrea gigas,

Cerastoderma edule and Ruditapes philippinarum) in the Nord Modc salt marshes (Gironde estuary, France). Science of the Total Environment 337, 265-280.

Bervoets, L., Van Campenhout, K., Reynders, H., Knapen, D., Covaci, A., Blust, R., 2009. 
1 Bocquené, G., Bellanger, C., Cadiou, Y., Galgani, F., 1995. Joint action of combinations of

2 pollutants on the acetylcholinesterase activity of several marine species. Ecotoxicology 4, 2663279.

4

5 Bocquené, G., Roig, A., Didier. F., 1997. Cholinesterase from the common Oyster (Crassostrea 6 gigas): Evidnece for the presence of a soluble acetylcholinesterase intensive to 7 organophosphorous and carbamate inhibitors. Federation of European Biochemical Societies 8 Letters 407, 3, 261-266.

9

Bonacci, S, Crosi, I., Focard, S., 2009. CholinesterasesintheAntarcticscallop Adamussium colbecki: Characterization and sensitivity to pollutants. Ecotoxicology and Environmental Safety $72,1481-1488$.

Bradford, M., 1976. A rapid and sensitive assay of protein utilizing the principle of dye binding. Analytical Biochemistry 772, 248-264.

Choi, J.Y., Yang, D.B., Ju, H.J., Kim, K.T., Hong, G.H., Shin, K.H., 2006. Distribution characteristics of organophosphorous pesticides in Asan Bay, Korea. Journal of the Korean Society for Marine Environmental Engineering 9, 176-186. 
1 Dailianis, S., Domouhtsidou, G.P., Raftopoulou, E., Kalayianni, M., Dimitriadis, V.K., 2003.

2 Evaluation of neutral red retention assay, micronucleus test, acetylcholinesterase activity and a

3 signal transduction molecule (cAMP) in tissues of Mytilus galloprovincialis (L.), in pollution

4 monitoring. Marine Environmental Research 56, 443-470.

5

6 Dellali, M., Gnassia-Barelli, M., Romeo, M., Aissa, P., 2001. The use of acetylcholine

7 esterase activity in Ruditapes decussates and Mytilus galloprovincialis in the biomonitoring of

8 Bizerta lagoon. Comparative Biochemistry and Physiology Part C Toxicology \& Pharmacology

$9 \quad 130,227-235$.

10

Doran, W.J., Cope, W.G., Rada, R.G., Sandheinrich, M.B., 2001. Acetylcholinesterase inhibition

in the threeridge mussel (Amblma plicata) by chlorpyrifos: Implications for biomonitoring.

Ecotoxicology and Environmental Safety 49, 91-98.

Escartín, E., Porte, C., 1997. The use of cholinesterase and carboxylesterase activities from Mytilus galloprovincialis in pollution monitoring. Environmental Toxicology and Chemistry 16, 2090-2095.

Fairbrother, A., Bennett, R. S., Bennett, J. K., 1989. Sequential sampling of plasma cholinesterase in mallards (Anas platyrhynchos) as an indicator of exposure to cholinesterase inhibitors. Environmental Toxicology and Chemistry 8, 117-122. 
1 Flammarion, P., Migeon, B., Garric, J., 1996. Joint effect of copper sulfate and methidathion on

2 rainbow trout (Oncorhyncus mykiss) EROD and AChE activities. Bulletin of Environmental

3 Contamination and Toxicology 56, 440-445.

4

5 Flassch, J.P., Leborgne, Y., 1992. Introduction in Europe, from 1972 to 1980, of the Japanese

6 manila clam (Tapes philippinarum) and effects on aquaculture production and natural settlement.

7 ICES Marine Science, 12-13 June, Halifax 194, pp. 92-96.

8

9 Forget, J., Pavillon, J. F., Beliaeff, B., Bocquené, G., 1999. Joint action of pollutant combinations (pesticides and metals) on survival $\left(\mathrm{LC}_{50}\right.$ values) and acetylcholinesterase activity of Tigriopus brevicornis (copepoda, harpacticoïda). Environmental Toxicology and Chemistry $18,912-918$.

Galgani, F., 1992. Monitoring of pollutant biochemical effects on marine organisms of the French coast. Oceanologica Acta 15, 4, 355-364.

Galgani, F., Bocquené, G., 2000. Molecular biomarkers of exposure of marine organisms to organophosphorus pesticides and carbamates. In: Lagadic, L. (Ed.), Use of Biomarkers for Environmental Quality Assessment. Elsevier Science Publisher, pp. 113-137.

Galloway, T.S., Millward, N., Browne, M.A., Depledge, M.H., 2002. Rapid assessment of organophosphorous/carbamate exposure in the bivalve mollusk Mytilus edulis using combined esterase activities as biomarker. Aquatic Toxicology 61, 169-180. 
1 Jett, D.A., Navoa, R.V., Lyons Jr., M.A., 1999. Additive inhibitory action of chlorpyrifos and

2 polycyclic aromatic hydrocarbons on acetylcholinesterase activity in vitro. Toxicology Letters $3 \quad 105,223-229$.

4

5 Kang, J.J., Fang, H.W., 1997. Polycyclic aromatic hydrocarbons inhibit the activity of 6 acetylcholinesterase purified from electric eel. Biochemical and Biophysical Research 7 Communications 238, 367-369.

8

9 Kidd, H., James, D.R. (Eds.), 1991. The Agrochemicals Handbook, Third Edition. Royal Society of Chemistry Information Services, Cambridge, UK, pp. 5-14.

KORDI (Korea Ocean Research and Development Institute) 2002. Pollution Reducing

Strategies for the coastal Yellow Sea. KORDI Report BSPM 120-00-1413-4. Ministry of Marine

Affairs and Fisheries, pp. 31-250.

Kristoff, G., Guerreo, N.V., D’Angelo, A.M.P., Cochón, A.C., 2006. Inhibition of cholinesterase activity by azinphos-methyl in two fresh water invertebrates: Biomphalaria glabrata and Lumbriculus variegaus. Toxicology 222, 185-194.

Laing, I., Child A.R., 1996. Comparative tolerance of small juvenile paourdes (Tapes decussates

L.) and Manila clam (Tapes philippinarum) to low temperature. Journal of Experimental Marine Biology and Ecology 195, 267-285. 
on the effect of dichlorvos on two commercial bivalves. Aquaculture 138, 139-144.

Linde-Arias, A.R., Inácio, A.F., de Alburquerque, C., Freire, M.M., Moreira, J.C., 2008. Biomarkers in an invasive fish species, Oreochromis niloticus, to assess the effects of pollution in a highly degraded Brazilian River. Science of the Total Environment 339, 186-192.

Lionetto, M.G., Caricato, R., Giordano, M.E., Pascariello, M.F., Marinosci, L., Schettino, T., 2003. Integrated use of biomarkers (acetylcholinesterase and antioxidant enzyme activities) in Mytilus galloprovincialis and Mullus barbatus in an Italian coastal marine area. Marine Pollution Bulletin 46, 324-330.

Magni, P., De Falco, G., Falugi, C., Franzoni, M., Monteverde, M., Perrone, E., Sgro, M., Bolognesi, C., 2006. Genetoxicity biomarkers and acetylcholinesterase activity in natural populations of Mytilus galloprovincialis among a pollution gradient in the Gulf of Oristano (Sardinia, western Mediterranean). Environmental Pollution 142, 65-72.

Matozzo, V., Tomei, A., Marin, M.G., 2005. Acetylcholinesterase as a biomarker of exposure to neurotoxic compounds in the clam Tapes philippinarum from the Lagoon of Venice. Marine Pollution Bulletin 50, 1686-1693.

Mayer, F.L., Ellersieck, M.R., 1986. Manual of Acute Toxicity: Interpretation and Data Base for 410 Chemicals and 66 Species of Freshwater Animals. Resource Publication 160. U.S. Department of Interior, Fish and Wildlife Service, Washington, DC, pp. 5-73. 
1 McHenery, J.G., Linley-Adams, G.E., Moore, D.C., Rodger, G.K., Davies, I.M., 1997.

2 Experimental and field studies of effects of dichlorvos exposure on acetylcholinesterase activity

3 in the gills of the mussel, Mytilus edulis L.. Aquatic Toxicology 38, 125-143.

5 Mohamed, B., Rym, B.D., Amor, E.A., Hamadi, B., 2003. Genotoxicity, catalase and 6 acetylcholinesterase in the assessment of the pollution status of some sites on the Tunisian $7 \quad$ littoral. Bulletin of Environmental Contamination and Toxicology 70, 854-860.

8

Mora, P., Michel, X., Narbonne, J., 1999. Cholinesterase activity as potential biomarker in two bivalves. Environmental Toxicology and Pharmacology 7, 253-260.

Moulton, C.A., Fleming, W.J., Purnell, C.E., 1996. Effects of two cholinesterase-inhibiting pesticides on freshwater mussels. Environmental Toxicology and Chemistry 15, 131-137.

Oliviera, M.M., Silva Filho, M.V., Cunha Bastos, V.L.F., Fernandes, F.C., Chunha Bastos, J., 2007. Brain acetylcholinesterase as a marine pesticide biomarker using Brazilian fishes. Marine Environmental Research 63, 303-312.

Payne, J.F., Mathieu, A., Melvin, W., Fancey, L.L., 1996. Acetylcholinesterase, an old biomarker with a new future? Field trials in association with two urban rivers and a paper mill in new Foundland. Marine Pollution Bulletin 32, 225-231.

Pfeifer, S., Schiedek, D., Joachim, J.W., 2005. Effect of temperature and salinity on acetylcholinesterase activity, a common pollution biomarker, in Mytilus sp. from the south- 
western Baltic Sea. Journal of Experimental Marine Biology and Ecology 320, 93-103.

Radenac, G., Bocquené, G., Fichet, D., Miramand, P., 1998. Contamination of a dredgedmaterial disposal site (La Rochelle Bay, France). The use of the acetylcholinesterase activity of Mytilus edulis (L.) as a biomarker of pesticides: the need for a critical approach. Biomarkers 3, 305-315.

Romani, R., Corsi, I, Bonacci, S., Focardi, S., De Medio, G.E., De Santis, A., Incarnato, F., Giovannini, E., Rosi, G., 2006. Organophosphate-resistant forms of acetylcholinesterases in two scallops-the Antarctic Adamussium colbecki and the Mediterranean Pecten jacobaeus. Comparative Biochemistry and Physiology Part B 145,188-196.

Senger, M.R., Rosemberg, D.B., Rico, E.P., de Bem Arizi, M., Dias, R.D., Bogo, M.R., Bonan, C.D., 2006. In vitro effect of zinc and cadmium on acetylcholinesterase and ectonucleotidase activities in zebrafish (Danio rerio) brain. Toxicology in Vitro 20, 954-958.

Sturm, A., Radau, T.S., Hahn, T., Scultz, R., 2007. Inhibition of rainbow trout acetylcholinesterase by aqueous and suspended particle-associated organophosphorous insecticides. Chemosphere 68, 605-612.

Toba, M., Natsume, y., Yamakawa, H., 1993, Reproductive cycles of manila clams Ruditapes phillipinarum collected from Funabashi waters, Tokyo bay. Nippon Suisan Gakkaishi 59, 15-22. 
1 Pesticide Exposure in the Freshwater Mussel Elliptio complanata. Publication No. 95-4F23,

2 U.S. Fish and Wildlife Service, Southeast Region, Atlanta, GA.

3

4 WHO, 2005. The WHO recommended classification of pesticides by hazard and guidelines to 5 classification: 2004. World Health Organization, pp.16-26.

6

7 Yu, J., Li, D.H., Kim, K.T., Yang, D.B., Yang, J.S., 2001. Distribution of Organophosphorus

8 pesticides in some estuarine environments in Korea. Journal of Fisheries Science and 9 Technology 4, 201-207.

10 


\section{Research highlights}

2

3 The acetylthiocholine (ATC) - cleaving cholinesterase (ChE) activity in Manila clam, which is

4 widely distributed throughout the coastal environment of Korea, was assayed as a potentially

5 useful biomarker of organophosphorous pesticides (OPs). We determined the ATC-cleaving ChE

6 activity of the Manila clam (R. philippinarum), widely distributed throughout intertidal zone of

7 Korea, to be a suitable biomarker for addressing pesticide contamination. ChE activity in the

8 adductor muscle of clams was significantly reduced with increases in organophosphorous

9 pesticide (OPs) dose, indicating a clear dose-response relationship. Clams from the 23 stations

10 on the mid-western coast of Korea indicated spatial variations in ChE activity. In order to

11 explain the spatial variations in ChE activity various contaminants in seawater and sediments of

12 study area were compared to ChE activity. Only IBP concentration in seawater showed a

13 significant relationship with $\mathrm{ChE}$ activity in Manila clams. Since Manila clams, $R$.

14 philippinarum, dwell in the intertidal zone, they may experience the greatest continuous

15 exposure to OP contaminants. Our results suggest that ChE activity in the adductor muscle of $R$.

16 philippinarum can be effectively utilized as a biomarker of organophosphorous pesticides (OPs)

17 in the coastal and estuarine environment. 
Table List

Table $1 . \mathrm{EC}_{50}-24 \mathrm{~h}$ values of OPs in the Manila clam, $R$. philippinarum, and their hazard classifications.

Table 2. (a) ChE activity (nmole $\mathrm{min}^{-1} \mathrm{mg}^{-1}$ protein) in the Manila clam, R. philippinarum, on the Western coast of Korea. (b) Results of one-way ANOVA results $(\alpha=0.05)$.

Table 3. (a) Chemical parameters of sea water from the Western coast of Korea. (b) Results of nonparametric correlation; Spearman's rank test. 
Table 1. $\mathrm{EC}_{50}-24 \mathrm{~h}$ values of OPs in the Manila clam, R. philippinarum, and their hazard classifications.

\begin{tabular}{cccc}
\hline $\begin{array}{c}\text { Organophosphorous } \\
\text { pesticide }\end{array}$ & $\mathrm{EC}_{50}-24 \mathrm{~h}$ & $\begin{array}{c}95 \% \text { confidence } \\
\text { limit }\end{array}$ & Classification by hazard $^{\mathrm{a}}$ \\
\hline Methidathion & $7.16 \mathrm{\mu g} \mathrm{l}^{-1}$ & $5.05-9.86 \mathrm{~g} \mathrm{l}^{-1}$ & Highly hazardous (Class Ib) \\
chlorpyrifos & $0.34 \mathrm{mg} \mathrm{l}^{-1}$ & $0.23-0.49 \mathrm{mg} \mathrm{l}^{-1}$ & Moderately hazardous (Class II) $^{-1}$ \\
diazinon & $3.01 \mathrm{mg} \mathrm{l}^{-1}$ & $1.60-12.18 \mathrm{mg} \mathrm{l}^{-1}$ & Moderately hazardous (Class II) \\
IBP & $3.41 \mathrm{mg} \mathrm{l}^{-1}$ & $2.21-7.77 \mathrm{mg} \mathrm{l}^{-1}$ & Slightly hazardous (Class III)
\end{tabular}

$\mathrm{EC}_{50} \mathrm{~s}$ with a $95 \%$ confidence limit for effective concentration were determined using probit analysis.

a Classification by hazard is the WHO-recommended classification of pesticides according to hazard (World Health Organization, 2005). 
Table 2. (a) ChE activity (nmole $\mathrm{min}^{-1} \mathrm{mg}^{-1}$ protein) in the Manila clam, $R$. philippinarum, on the Western coast of Korea.

\begin{tabular}{|c|c|}
\hline Station & $\begin{array}{c}\text { ChE activity } \\
\text { (nmole } \min ^{-1} \mathrm{mg}^{-1} \text { protein) }\end{array}$ \\
\hline St. 1 & $11.64 \pm 2.36$ \\
\hline St. 2 & $8.09 \pm 2.05$ \\
\hline St. 3 & $10.80 \pm 1.92$ \\
\hline St. 4 & $7.88 \pm 3.39$ \\
\hline St. 5 & $11.11 \pm 4.69$ \\
\hline St. 6 & $11.98 \pm 3.88$ \\
\hline St. 7 & $9.11 \pm 2.55$ \\
\hline St. 8 & $11.80 \pm 2.11$ \\
\hline St. 9 & $11.66 \pm 3.21$ \\
\hline St. 10 & $13.24 \pm 6.13$ \\
\hline St. 11 & $9.40 \pm 2.63$ \\
\hline St. 12 & $6.43 \pm 0.96 * *$ \\
\hline St. 13 & $11.83 \pm 1.85$ \\
\hline St. 14 & $6.64 \pm 2.16 *$ \\
\hline St. 15 & $11.27 \pm 2.63$ \\
\hline St. 16 & $6.14 \pm 2.95 * *$ \\
\hline St. 17 & $11.62 \pm 2.80$ \\
\hline St. 18 & $9.57 \pm 0.80$ \\
\hline St. 19 & $10.55 \pm 3.25$ \\
\hline St. 20 & $9.21 \pm 3.27$ \\
\hline St. 21 & $8.29 \pm 2.58$ \\
\hline St. 22 & $8.70 \pm 1.65$ \\
\hline St. 23 & $10.73 \pm 2.60$ \\
\hline
\end{tabular}

Data are presented as the mean \pm standard deviation (S.D), $n=5$ for each sample site.

*Asterisks indicate a significant difference compared to the control site (St. 10). Tukey's post hoc test: * $p<0.1, * * p<0.05$.

(b) Results of one-way ANOVA results $(\alpha=0.05)$.

\begin{tabular}{cccccc}
\hline & Sum of Squares & df & Mean Square & F & Sig. \\
\hline Between Groups & 434.483 & 22 & 19.749 & 2.405. & 0.0019
\end{tabular}

In each raw, means followed by different superscripts are significantly different from each other (One-way ANOVA, $p<$ $0.05)$. 
Table 3. (a) Chemical parameters of the Western coast of Korea.

\begin{tabular}{|c|c|c|c|}
\hline Station & $\begin{array}{l}\text { Salinity } \\
(\% o)\end{array}$ & 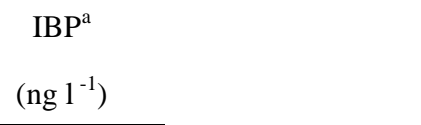 & \\
\hline St. 1 & - & - & \\
\hline St. 2 & 31.76 & - & \\
\hline St. 3 & 31.29 & $<1$ & \\
\hline St. 4 & 31.35 & $<1$ & \\
\hline St. 5 & - & $<1$ & \\
\hline St. 6 & 33.27 & $<1$ & \\
\hline St. 7 & 31.93 & - & \\
\hline St. 8 & 32.02 & $<1$ & \\
\hline St. 9 & 31.83 & $<1$ & \\
\hline St. 10 & 31.8 & $<1$ & \\
\hline St. 11 & 32.57 & - & \\
\hline St. 12 & 31.83 & - & \\
\hline St. 13 & 31.03 & 32 & \\
\hline St. 14 & - & - & \\
\hline St. 15 & - & $<1$ & \\
\hline St. 16 & - & - & \\
\hline St. 17 & 29.18 & 394 & \\
\hline St. 18 & - & $<1$ & \\
\hline St. 19 & 30.89 & 16 & \\
\hline St. 20 & 29.1 & 40 & \\
\hline St. 21 & 30.46 & 26 & \\
\hline St. 22 & 30.05 & 138 & \\
\hline St. 23 & - & 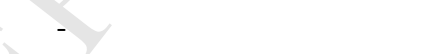 & \\
\hline \multicolumn{4}{|c|}{$\begin{array}{l}\text {-, not measured } \\
\text { a IBP(KORDI , 2002) }\end{array}$} \\
\hline & 8 & Salinity with ChE activity & IBP with $\mathrm{ChE}$ activity \\
\hline correla & efficient & 0.222 & -0.6 \\
\hline & & 0.408 & $0.039 *$ \\
\hline
\end{tabular}

*Asterisks: Correlation is significant at the 0.05 level ( 2 tailed). 


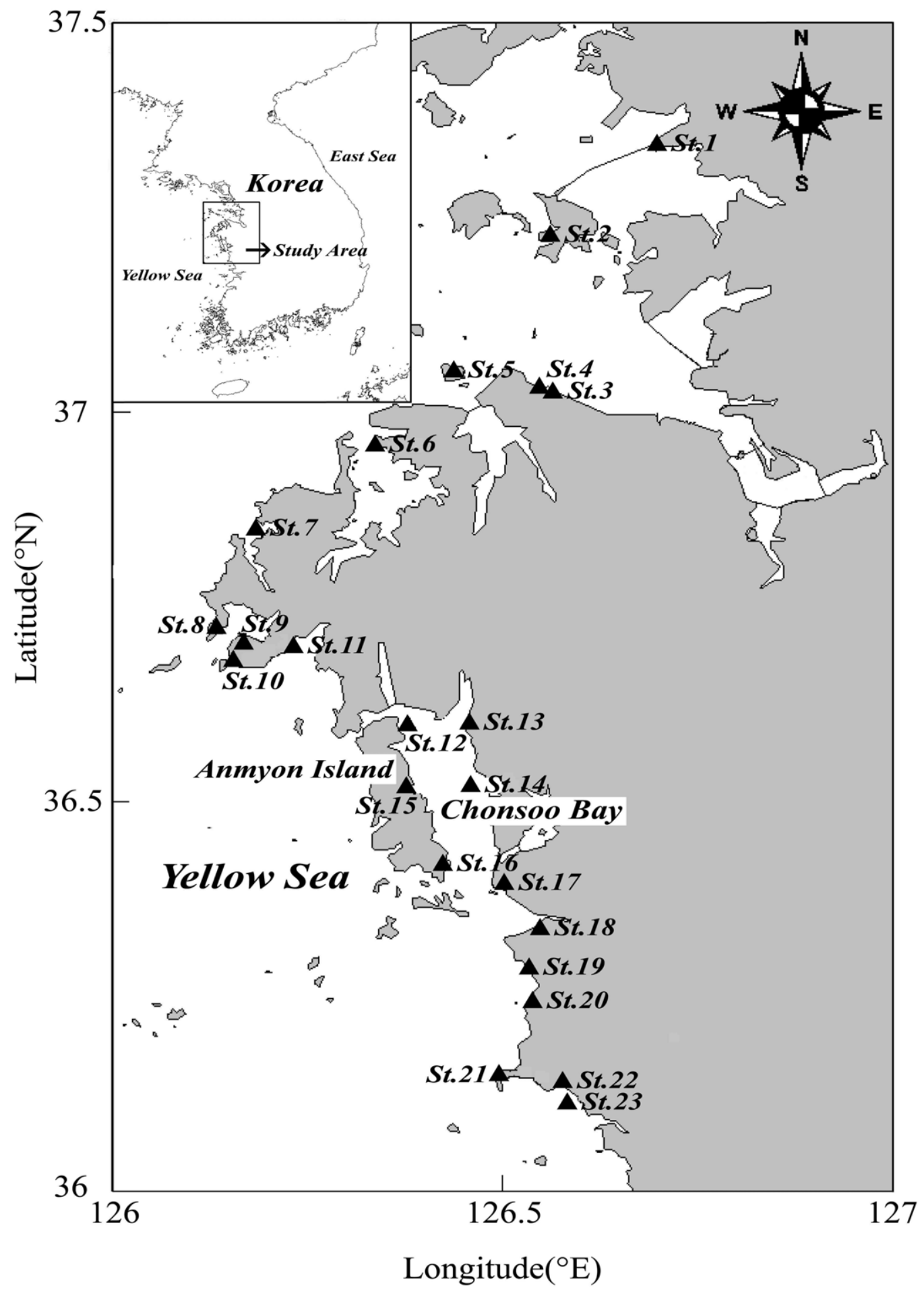

